Proc. Estonian Acad. Sci. Biol. Ecol., 2005, 54, 1, 40-52

\title{
Hepatotoxic cyanobacterial peptides in Estonian freshwater bodies and inshore marine water
}

\author{
Risto Tanner $^{\mathrm{a} *}$, Külli Kangur ${ }^{\mathrm{b}}$, Lisa Spoof ${ }^{\mathrm{c}}$, and Jussi Meriluoto ${ }^{\mathrm{c}}$ \\ a National Institute of Chemical Physics and Biophysics, Akadeemia tee 23, 12618 Tallinn, Estonia \\ b Võrtsjärv Limnological Station, Institute of Zoology and Botany, Estonian Agricultural University, \\ 61101 Rannu, Tartumaa, Estonia \\ c Department of Biochemistry and Pharmacy, Åbo Akademi University, Tykistökatu 6A, FIN-20520 \\ Turku, Finland
}

Received 3 September 2004, in revised form 6 January 2005

\begin{abstract}
Mass growths of cyanobacteria (blue-green algae), leading to the production of scums and mats, occur sometimes in nutrient-enriched waterbodies throughout the world, including Estonia. This paper shortly summarizes information about cyanobacterial toxins, reports first results of liquid chromatographic-mass spectrometric analyses of cyanobacterial toxins in some waterbodies in Estonia, and attempts to assess possible risk of associated local health problems by drawing some parallels with the situation in neighbouring Finland. The risk of drinking toxin-containing water by the population of Narva in connection with some toxic cyanobacterial bloom in northern Lake Peipsi is outlined. The need for regular monitoring of toxicity of cyanobacterial blooms as well as deeper research of ecological consequences of blooms of toxic cyanobacteria is emphasized in this connection.
\end{abstract}

Key words: Lake Peipsi, Lake Pühajärv, Narva water supply, cyanobacteria, toxins.

\section{INTRODUCTION}

Eutrophication, a biological response to the excess input of nutrients into a waterbody, is a well-known consequence of human activities worldwide (Moss, 1988) as well as in Estonia (Starast et al., 2001). Eutrophication promotes blooms of cyanobacteria. Enhanced phosphorus concentrations will raise the intensity of blooms (Reynolds \& Petersen, 2000). The decay of cyanobacterial blooms may cause significant depletion of dissolved oxygen from the water column and result in direct fish kills in waterbodies, as was observed in 2002 in Lake Peipsi in Estonia (Kangur et al., 2003, 2005). The presence of cyanobacteria can also create

*Corresponding author, risto@kbfi.ee 
severe odour problems and reduce water quality in terms of human water use (Meriluoto et al., 2000a).

Besides a possible indirect influence on the ecological balance in waterbodies, cyanobacteria have an additional concern to water environment because of the common ability of these organisms to produce a range of potent toxins, including hepatotoxins, neurotoxins, and skin irritants (see Chorus \& Bartram, 1999 for review). There is evidence that the toxins have caused deaths of livestock, other domestic animals, and wildlife, and present hazards to human health via drinking water, accidental ingestion of cyanobacterial bloom material, and recreational contact (see Chorus \& Bartram, 1999 for review). A case of fatal cyanobacterial intoxication of human beings was reported in connection with haemodialysis in Brazil (Jochimsen et al., 1998; Pouria et al., 1998).

Cyanobacterial toxins are currently grouped into classes according to their modes of toxicity in animals (see Chorus \& Bartram, 1999 for review). The neurotoxins include anatoxin-a and homoanatoxin-a, which are postsynaptic cholinergic nicotine agonists and neuromuscular blocking agents. Anatoxin-a(S), an organophosphate neurotoxin, is an inhibitor of acetylcholinesterase. Saxitoxins (carbamate alkaloid neurotoxins) are well-known in the marine context as products of dinoflagellate red tides, but a range of freshwater cyanobacteria can produce some of these neurotoxins also. The neurotoxins cause death by respiratory arrest.

Microcystins and nodularins are cyclic heptapeptides and pentapeptides, respectively. The general structure of microcystins is cyclo(-D-Ala-L- $X$-D-erythromethylAsp(iso-linkage)-L-Z-Adda-D-Glu(iso-linkage)- $N$-methyldehydro-Ala) where Adda stands for the unique $\beta$-amino acid 3-amino-9-methoxy-2,6,8-trimethyl-10phenyldeca-4(E),6(E)-dienoic acid (Rinehart et al., 1988). Nodularins are cyclic pentapeptides with the general structure cyclo(-D-erythro-methylAsp(iso-linkage)L-Z-Adda-D-Glu(iso-linkage)-2-(methylamino)-2(Z)-dehydrobutyric acid) (Fig. 1).

More than 70 microcystin variants and several nodularin variants are known (see Chorus \& Bartram, 1999 for review). They are hepatotoxic to animals and tumour-promoters. Disruption of liver structure and function occurs with haemorrhage into the liver and death by hypovolemic shock. At the molecular level, microcystins and nodularins inhibit protein phosphatases 1 and 2A (MacKintosh et al., 1990, 1995). Microcystins are produced by several common freshwater cyanobacterial genera including Microcystis, Anabaena, and Planktothrix (Oscillatoria) while nodularin is produced by the brackish water cyanobacterium Nodularia. Recently microcystin-LR was also found in pelagic cyanobacterial blooms in the northern Baltic Sea (Karlsson et al., 2005). The lethal doses giving $50 \%$ deaths $\left(\mathrm{LD}_{50}\right.$; mouse, i.p.) for different microcystins and nodularins vary from about $50 \mu \mathrm{g} / \mathrm{kg}$ to over $1 \mathrm{mg} / \mathrm{kg}$ (see Chorus \& Bartram, 1999 for review).

Mass developments of cyanobacteria such as Anabaena flos-aquae, A. spiroides, Aphanizomenon flos-aquae, Microcystis aeruginosa, and Gloeotrichia echinulata have occasionally been observed in Lake Peipsi since 1895 (reviewed by Laugaste et al., 2001) as well as in smaller lakes in Estonia, but there has been very little information available about the real toxicity of cyanobacterial blooms in Estonia. 
$\begin{array}{lll}\text { Microcystin- } X Z & \text { (6) D-Glu (iso) } & \text { (7) } \mathrm{N} \text {-methyldehydroAla (Mdha) }\end{array}$

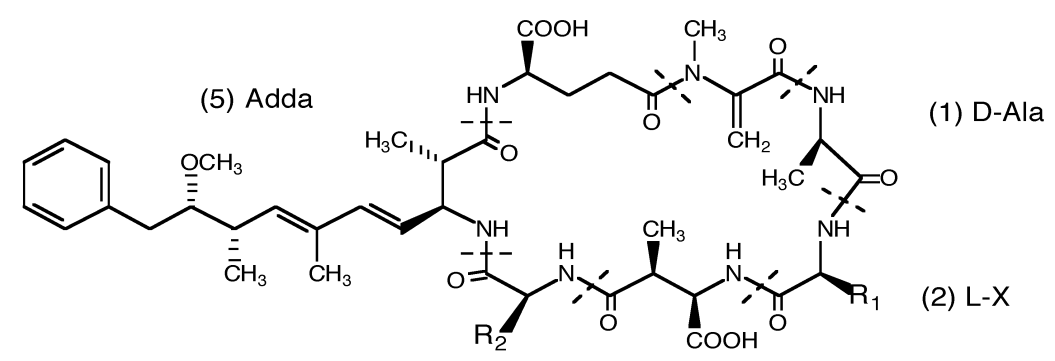

(4) L-Z (3) D-erythro- $\beta$-methylAsp (iso)

Nodularin-Z

(4) D-Glu (iso)

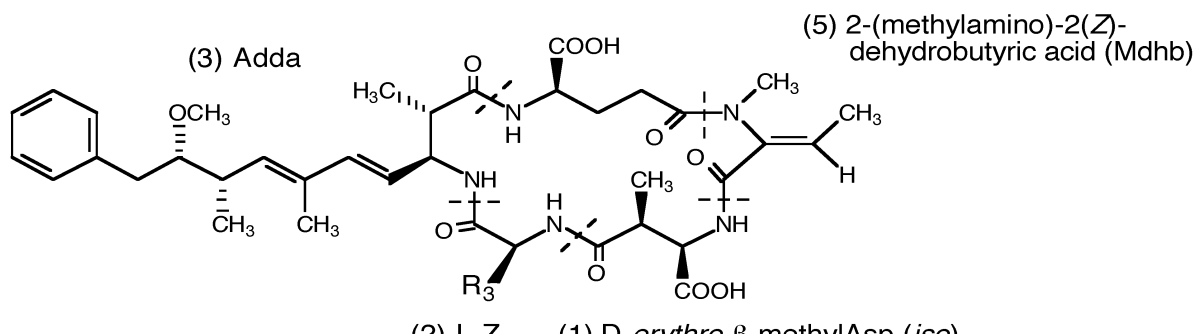

(2) L-Z (1) D-erythro- $\beta$-methylAsp (iso)

Fig. 1. General structure of microcystins and nodularins. $\mathrm{X}$ and $\mathrm{Z}$ stand for variable amino acids in different variants of the toxins.

The aim of this work was to check possible toxin occurrence in cyanobacterial blooms in Estonian inland waterbodies as well as in inshore marine water and compare the pattern of microcystins with those found in some waterbodies of neighbouring countries. The work summarizes results of first chromatographic analyses of cyanobacterial toxins in Estonia. Results are discussed in terms of local need for awareness of the likelihood and significance of cyanobacterial toxin production and of relevant health and environment risk assessment in Estonia.

\section{EXPERIMENTAL}

\section{Chemicals}

HPLC-grade methanol and acetonitrile were purchased from Rathburn (Walkerburn, UK), acetic acid of luminescence measurement grade from Fluka (Buchs, Switzerland). Silasorb C18 (LC) $15 \mu \mathrm{m}$ was purchased from Chemapol (Prague, Czech Republic). Water was purified to $18.2 \mathrm{M} \Omega \mathrm{cm}$ on a Milli-Q plus system (Millipore, Molsheim, France). All other reagents used were of analytical grade. 


\section{HPLC-MS apparatus}

The HPLC system consisted of a low pressure quaternary gradient pump unit, a column oven, and a diode array spectrophotometric detector (DAD), all of Series 200 instruments from Perkin Elmer (Norwalk, CT, USA), a mass spectrometer (MS) with electrospray ionization API 150EX from PE Sciex Instruments (Foster City, CA, USA), a manual injector from Rheodyne (Rohnert Park, CA, USA), and a Discovery RP Amide $\mathrm{C}_{16}$ column $25 \mathrm{~cm} \times 3 \mathrm{~mm}$ ID, particle size $5 \mu \mathrm{m}$, from Supelco (Bellefonte, PA, USA). The column outflow was splitted by means of a P-450 low-pressure microsplitter valve from Upchurch Scientific (Oak Harbor, WA, USA). The splitting ratio between DAD and MS was adjusted to 5:1, and a backpressure unit of $0.67 \mathrm{MPa}$ from Optimize Technologies (Oregon City, OR, USA) was connected to the outflow from DAD for the stabilization of this ratio. The eluent was mixed from $0.05 \%$ acetic acid in water (A) and $0.05 \%$ acetic acid in acetonitrile (B) with time program from $20 \%$ of B to $75 \%$ of B in $30 \mathrm{~min}$, followed by washing the column with pure acetonitrile for $5 \mathrm{~min}$. The total flow rate $0.6 \mathrm{~mL} / \mathrm{min}$ was used continuously and the column was thermostatted at $30^{\circ} \mathrm{C}$. The UV absorbance was registered at $200-400 \mathrm{~nm}$ with spectral bandwidth $2 \mathrm{~nm}$ and measurement interval $880 \mathrm{~ms}$. The absorbance data were analysed with the TurboChrom Workstation software from Perkin Elmer and MS data with Analyst version 1.1 software from PE Sciex.

\section{Study sites}

Lake Peipsi with its mean surface area of $3555 \mathrm{~km}^{2}$ is the largest freshwater body in the Baltic region and the fourth in Europe. It is located on the border between Estonia and Russia and is of great economic and recreational importance for both countries. It serves also as the drinking water source for the industrial town of Narva in Estonia and for Ivangorod in Russia. Narva Reservoir (an artificial lake) is located on the Narva River, the outflow from Lake Peipsi. Smaller lakes Pühajärv and Ähijärv, which are also included in this study, are situated in the southeastern hilly area of Estonia and are popular recreational waterbodies of mainly local importance. Hiiumaa Island, the second largest Estonian island, is located between the western coast of Estonian mainland and the Baltic Proper. Together with the largest island, Saaremaa, it separates the small relatively closed Väinameri Sea area from the Baltic Proper. The Kassari beach belongs to the coast bordering this sea area from the north.

\section{Sampling and sample preparation}

Fixed sampling points for water quality research on Lake Peipsi are shown in Fig. 2. 


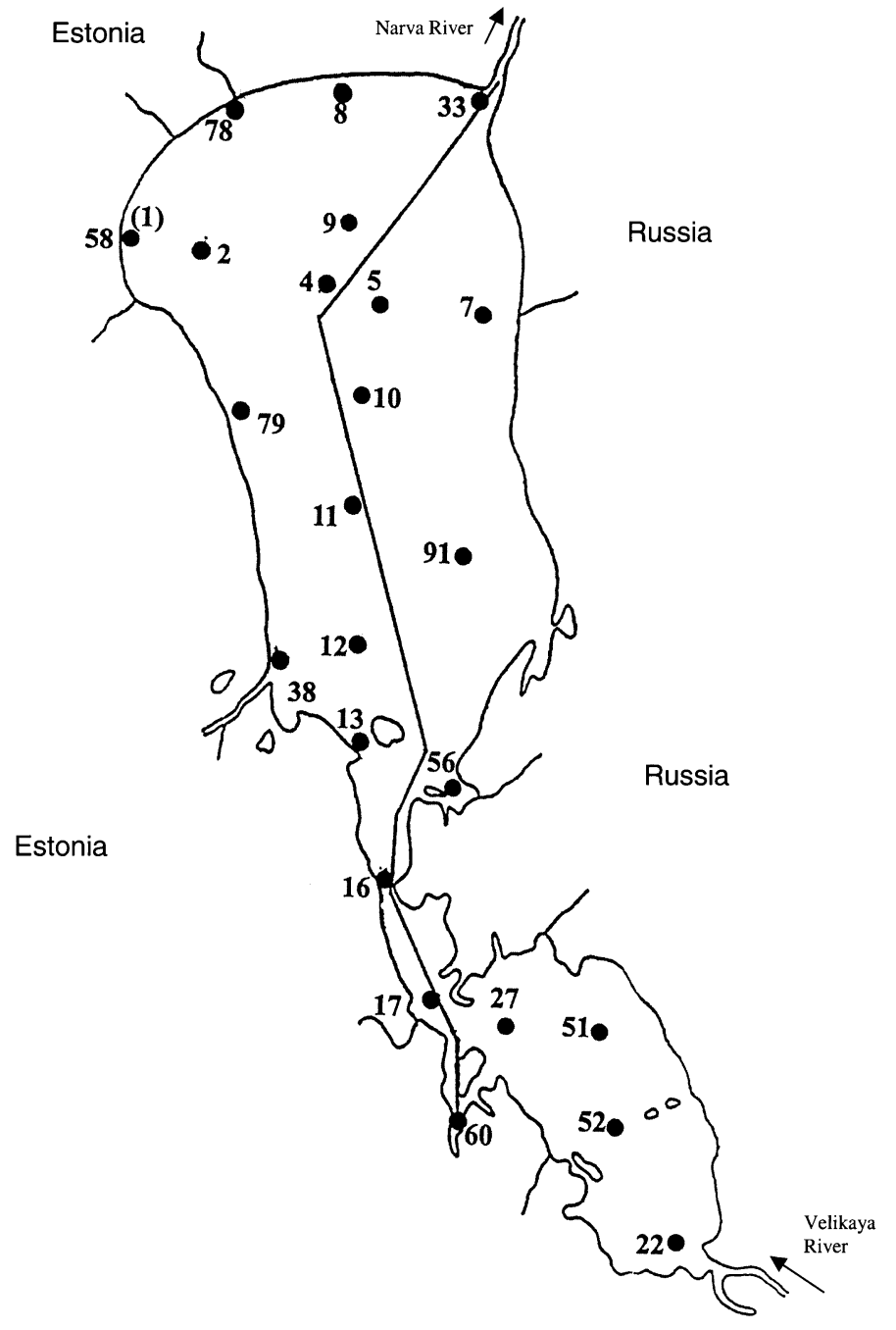

Fig. 2. Stationary sampling points for water quality research on Lake Peipsi.

The water samples were assigned the same numbers as the sampling points where they were taken (Fig. 2). Water sampling was performed with a Ruttner sampler from a depth of $0.1-1.0 \mathrm{~m}$ to plastic bottles, freezed within the day of sampling, and stored till analyses at the temperature from -15 to $-20^{\circ} \mathrm{C}$. The phytoplankton samples were preserved with Lugol's solution. The fixed materials were identified and counted using the Utermöhl (1958) technique. 
Pretreatment of samples before final chromatography differed in different years. The water samples of the year 2002 and earlier were freeze-dried and stored at the temperature from -15 to $-20^{\circ} \mathrm{C}$. The dry matter content in the water samples was calculated from the weighing data before and after drying of $10 \mathrm{~mL}$ aliquots of the sample under an IR lamp till constant weight. Charges of $0.5 \mathrm{~g}$ of freeze-dried powder were wetted with $0.5 \mathrm{~mL}$ of water one day before analysis, mixed by keeping in the ultrasonic bath for $15 \mathrm{~min}$, and left overnight in the freezer again. Next morning $1.5 \mathrm{~mL}$ of methanol was added to each sample, followed by treatment in the ultrasonic bath for $45 \mathrm{~min}$ and centrifugation at $500 \times g$ for $20 \mathrm{~min}$. The supernatant was filtered through a thin layer of Silasorb $\mathrm{C} 18$ adsorbent $(0.25 \mathrm{mg}$ of the adsorbent on the porous glass filter with an active diam. $3 \mathrm{~mm}$ ) and samples of 10-20 $\mu \mathrm{L}$ were injected into the chromatograph.

The water samples of the years 2003 and 2004 were defrosted by leaving at room temperature overnight, then freezed again at the temperature from -15 to $-20^{\circ} \mathrm{C}$. On the day of analysis the samples were defrosted in the water bath at $75-80^{\circ} \mathrm{C}$, kept at this temperature for $20 \mathrm{~min}$ after total melting, and treated in the ultrasonic bath for $45 \mathrm{~min}$ at room temperature. Ultrasonicated water was filtered through a glass fibre filter disc (Millipore, Billerica, MA, USA) and an aliquot of $25-100 \mathrm{~mL}$ of filtrate was sucked through the preconditioned $(1 \mathrm{~mL}$ of methanol followed by $1 \mathrm{~mL}$ of water) OASIS HLB Vac $60 \mathrm{mg}$ (Waters, Milford, MA, USA) SPE cartridge by a peristaltic pump adjusted to the flow rate $0.6 \mathrm{~mL} / \mathrm{min}$. The cartridge was washed with $1 \mathrm{~mL}$ of $5 \%$ methanol in water, microcystins eluted with 1 or $2 \mathrm{~mL}$ of $75 \%$ methanol in water, and $100 \mu \mathrm{L}$ of the solution was injected into the chromatograph.

\section{Toxin identification and concentration calculation}

Microcystins and nodularin- $\mathrm{R}$ were identified according to retention time, absorption spectra with characteristic maximum near $238 \mathrm{~nm}$, and ion masses. Methanolic extract of Microcystis PCC7820 (Institut Pasteur, Paris) and Anabaena sp. 90 (culture collection of Prof. Kaarina Sivonen, University of Helsinki) spiked with commercial microcystin-YR (Calbiochem, La Jolla, CA, USA) and methanolic extracts of Baltic Sea Nodularia containing nodularin-R (MC-MIX from Spoof et al., 2001) were used as reference materials. Quantitative calculations were based on calibration curves obtained with highly purified microcystin-LR samples determined spectrophotometrically at $238 \mathrm{~nm}$ in methanol (Meriluoto, 2000). Equal molar responses in HPLC-DAD were assumed for all variants of microcystins and nodularins at $238 \mathrm{~nm}$ as they share the common main chromophore, the conjugated double bonds of Adda. The toxin content of the samples was expressed in microgram toxin per litre of water sample. 


\section{RESULTS}

Demethylmicrocystin-RR, microcystin-RR, microcystin-YR, demethylmicrocystin-LR, and microcystin-LR were identified in bloom samples from Lake Peipsi both in September 2002 and in August 2003 (Table 1), when Anabaena spp. and Microcystis spp. were observed as the dominant species in cyanobacterial blooms.

No microcystins could be found in the samples from the massive summer bloom of mainly Gloeotrichia echinulata in Lake Peipsi in 2002. However, only a couple of weeks later another species became dominant in the bloom and

Table 1. Concentrations of microcystins found in the water of Lake Peipsi

\begin{tabular}{|c|c|c|c|c|c|c|c|}
\hline \multirow{2}{*}{$\begin{array}{l}\text { Sampling } \\
\text { point }\end{array}$} & \multirow{2}{*}{$\begin{array}{l}\text { Sampling } \\
\text { date }\end{array}$} & \multirow{2}{*}{$\begin{array}{l}\text { Dominant } \\
\text { species }^{\mathrm{a}}\end{array}$} & \multicolumn{5}{|c|}{ Concentrations of microcystins, $\mu \mathrm{g} / \mathrm{L}$} \\
\hline & & & McdmRR & McRR & McYR & McdmLR & McLR \\
\hline $\begin{array}{l}\text { Many } \\
\text { points }\end{array}$ & Jul-Aug 2002 & $\begin{array}{c}\text { Gloeotrichia } \\
\text { echinulata }\end{array}$ & $\mathrm{nf}^{\mathrm{b}}$ & $\mathrm{nf}^{\mathrm{b}}$ & $\mathrm{nf}^{\mathrm{b}}$ & $\mathrm{nf}^{\mathrm{b}}$ & $\mathrm{nf}^{\mathrm{b}}$ \\
\hline $2^{\mathrm{c}}$ & 2 Sep 2002 & $\begin{array}{l}\text { M. viridis, } \\
\text { A. circinalis }\end{array}$ & 2.05 & 21.5 & 8.8 & 1.7 & 16 \\
\hline $78^{\mathrm{d}}$ & 8 Sep 2002 & $\begin{array}{l}\text { M. viridis, } \\
\text { A. circinalis }\end{array}$ & 101 & 1120 & 319 & 57 & 586 \\
\hline $4^{\mathrm{c}}$ & 11 Aug 2003 & $\begin{array}{l}\text { M. botrys, } \\
\text { Gloeotrichia } \\
\text { echinulata }\end{array}$ & 0.01 & 0.05 & $\mathrm{nf}$ & $\mathrm{nf}$ & 0.03 \\
\hline $7^{\mathrm{c}}$ & 11 Aug 2003 & $\begin{array}{l}\text { M. wesenbergii, } \\
\text { M. botrys }\end{array}$ & 0.01 & 0.02 & $\mathrm{nf}$ & $\mathrm{nf}$ & 0.02 \\
\hline $11^{\mathrm{c}}$ & 11 Aug 2003 & $\begin{array}{l}\text { M. viridis, } \\
\text { A. lemmermannii }\end{array}$ & $\mathrm{nf}$ & 0.01 & $\mathrm{nf}$ & $\mathrm{nf}$ & 0.04 \\
\hline $16^{\mathrm{c}}$ & 4 Aug 2003 & M. viridis & 0.02 & 0.16 & 0.06 & 0.06 & 0.16 \\
\hline $17^{\mathrm{c}}$ & 4 Aug 2003 & M. viridis & 0.05 & 0.32 & 0.10 & 0.10 & 0.28 \\
\hline $17^{\mathrm{c}}$ & 4 Aug 2003 & M. viridis & 0.08 & 0.61 & 0.11 & 0.11 & 0.28 \\
\hline $17^{\mathrm{c}}$ & 12 Aug 2003 & $\begin{array}{l}\text { M. viridis, } \\
\text { M. wesenbergii }\end{array}$ & 0.07 & 0.67 & 0.11 & 0.11 & 0.24 \\
\hline $52^{\mathrm{c}}$ & 12 Aug 2003 & M. botrys, $M$. viridis & 0.05 & 0.25 & 0.12 & 0.12 & 0.19 \\
\hline $17^{\mathrm{d}}$ & $26 \mathrm{Jul} 2004$ & A. circinalis, $A$. fusca & $\mathrm{nf}$ & $\mathrm{nf}$ & $\mathrm{nf}$ & $\mathrm{nf}$ & $\mathrm{nf}$ \\
\hline $13^{\mathrm{d}}$ & $27 \mathrm{Jul} 2004$ & $\begin{array}{l}\text { A. crassa, } \\
\text { Aphanizomenon } \\
\text { flos-aquae }\end{array}$ & $\mathrm{nf}$ & $\mathrm{nf}$ & $\mathrm{nf}$ & $\mathrm{nf}$ & $\mathrm{nf}$ \\
\hline
\end{tabular}

a A.-Anabaena; M. - Microcystis.

b $\mathrm{nf}$ - analysed but not found.

c Mean water samples from the open area of the lake from a depth of $30-50 \mathrm{~cm}$.

d Water sample from the region of inshore accumulation of cyanobacterial mass. 
significant concentrations of microcystins were found (Table 1). The total concentration of microcystins in Lake Peipsi appeared to be of approximately 2 magnitudes greater in autumn 2002 than in summer 2003. Microcystin-LR was the only microcystin variant analysed in 2001-2002 in the samples from smaller lakes, and it was detected in all three samples analysed. More variants of microcystins were identified in the bloom in Lake Pühajärv in 2004 (Table 2).

The concentration of total nodularin-R was $40 \mu \mathrm{g} / \mathrm{L}$ in the water sample taken on 4 August 2003 from the Kassari plage area where blooming Nodularia spumigena had been accumulated by the wind. In the water samples taken $250 \mathrm{~m}$ to the right and left from the plage area, 28 and $220 \mu \mathrm{g} / \mathrm{L}$ of total nodularin-R was found, respectively.

Table 2. Concentrations of microcystins found in the water of some small Estonian lakes

\begin{tabular}{|c|c|c|c|c|c|c|c|}
\hline \multirow{2}{*}{$\begin{array}{l}\text { Sampling } \\
\text { point }\end{array}$} & \multirow{2}{*}{$\begin{array}{l}\text { Sampling } \\
\text { date }\end{array}$} & \multirow{2}{*}{$\begin{array}{l}\text { Dominant } \\
\text { species }^{\mathrm{a}}\end{array}$} & \multicolumn{5}{|c|}{ Concentrations of microcystins, $\mu \mathrm{g} / \mathrm{L}$} \\
\hline & & & McdmRR & McRR & McYR & McdmLR & McLR \\
\hline Pühajärv ${ }^{b}$ & 25 Jun 2004 & $\begin{array}{l}\text { M. botrys, } \\
\text { M. viridis, } \\
\text { M. flos-aquae, } \\
\text { M. wesenbergii, } \\
\text { A. lemmermannii }\end{array}$ & 11.5 & 8.3 & 2.0 & 1.8 & 3.2 \\
\hline Pühajärv $^{c}$ & 25 Jun 2004 & $\begin{array}{l}\text { M. botrys, } \\
\text { M. viridis, } \\
\text { M. flos-aquae, } \\
\text { M. wesenbergii, } \\
\text { A. lemmermannii }\end{array}$ & 0.53 & 0.44 & 0.09 & 0.05 & 0.2 \\
\hline Pühajärv $^{c}$ & 3 Jul 2001 & $\begin{array}{l}\text { M. botrys, } \\
\text { M. viridis, } \\
\text { M.flos-aquae, } \\
\text { M. wesenbergii }\end{array}$ & na & na & na & na & 1.1 \\
\hline Narva res. ${ }^{b}$ & 6 Sep 2002 & $\begin{array}{l}\text { A. circinalis, } \\
\text { M. viridis }\end{array}$ & na & na & na & na & 67 \\
\hline Ähijärv ${ }^{a}$ & 5 Jul 2001 & $\begin{array}{l}\text { M. flos-aquae, } \\
\text { Radiocystis geminata }\end{array}$ & na & na & na & na & 0.1 \\
\hline
\end{tabular}

a A.-Anabaena; M.-Microcystis.

b Water sample from the region of inshore accumulation of cyanobacterial mass.

c Mean water samples from the open area of the lake from the depth 30-50 cm.

d na-not analysed. 


\section{DISCUSSION}

The World Health Organisation (WHO) has proposed a provisional guideline value of $1 \mu \mathrm{g} / \mathrm{L}$ for the most common microcystin variant, microcystin-LR, in drinking water (WHO, 1998). This is one reason why sensitive, rapid, and simple microcystin tests have been worked out in addition to the development of more sophisticated methods used mainly in scientific research and central laboratories. Methods such as enzyme-linked immunosorbent assays (ELISAs) and protein phosphatase inhibition assays (PPI assays) have been developed to function as a first screen for microcystins and nodularins in drinking water as well as in cyanobacterial cell material (see Rapala et al., 2002 for review and comparisons). Chromatographic methods capable of individual quantitation of microcystins and nodularins complement the screening methods in more detailed investigations (see Meriluoto et al., 2000b for review). An often-encountered problem in microcystin chromatography is the separation of demethylated toxins from their non-demethylated analogues with different toxicities (Spoof et al., 2001). Microcystin-LW and -LF constitute a further example of a microcystin pair that is difficult to separate (Edwards et al., 1966). International standardization of analysis of microcystins is currently in progress. In the first intercomparison exercise between 27 laboratories severe discrepancies were observed both in quantitative and qualitative analysis of microcystins (Fastner et al., 2001). The combination of high selectivity of both $\mathrm{C}_{16}$ amide column (Spoof et al., 2001) and MS detection used in the present work seemed to provide a reliable method for the detection of minor differences between different varieties of microcystins.

Some plastic materials such as polypropylene pipette tips were found to partially absorb microcystin-LR from aqueous solutions (Hyenstrand et al., 2001). As plastic bottles were used for storing and transport of water samples in this study, it can be supposed that the real concentrations of microcystins might have been somewhat higher, especially in the case of lower concentrations shown in Tables 1 and 2.

Next morning forms, belong to the most common microcystins in countries around the Baltic Sea. In our earlier study (Spoof et al., 2003) freshwater and brackish-water samples were taken from 93 sampling stations on the Åland Islands, SW Finland, in 2001. The samples were analysed for biomass-bound microcystins and nodularin-R by chromatographic methods and ELISA. Microcystin concentrations equal to or higher than $0.2 \mu \mathrm{g} / \mathrm{L}$ were confirmed in 14 locations. The highest observed intracellular toxin concentration was $42 \mu \mathrm{g} / \mathrm{L}$. The common toxins detected were microcystin-RR, -LR, and -YR with variations in the degree of demethylation. In another study (Jurczak et al., 2004) the following major microcystins were found in Polish lakes and reservoirs: microcystin-RR, -AR, -YR, and -LR. In addition, several minor components including demethylated microcystins were observed. These findings from neighbouring Baltic countries do not essentially differ from our findings in Estonia with the exception that only microcystin-AR was not identified in our experiments. 
The growth of cyanobacteria in Lake Peipsi in summer 2002 was strongly enhanced by an early spring and an extremely hot summer as well as falling water level (Kangur et al., 2005). In July-August the biomass of cyanobacteria reached $250 \mathrm{~g} / \mathrm{m}^{3}$ and the concentration of chlorophyll was over $400 \mathrm{mg} / \mathrm{m}^{3}$ in the coastal area of the water. The bloom was accompanied by massive death of fish already in July-August when no microcystins could be found in the cyanobacterial mass (Kangur et al., 2005). Fish can usually survive in microcystin-containing water layers (Lindholm et al., 1999), but may be sensitive to the general water quality deterioration caused by massive algal blooms, including oxygen depletion during bloom decay. According to our study microcystins cannot be pointed out as the cause of fish kills in Lake Peipsi but other reasons, likely related to the cyanobacterial biomass and/or bioactive compounds in it, are a more feasible explanation of this ecological crisis. Ecological conditions in the lake that lead to fish kill are discussed in the article by Kangur et al. (2005). There is evidence also in recent literature that Microcystis may be toxic to fish after being eaten; besides acute toxicity, e.g. damage to liver, kidney, or gills, there are several sublethal and indirect effects that may reduce the growth rate by an enhanced energy demand: induction of detoxification enzymes, increased plasma levels of cortisol and glucose, inactivated ion regulation, and increased swimming activity (Kamjunke et al., 2002). Excess of cyanobacteria may be dangerous also to the success of reproduction of the industrially essential fish stock in the Baltic Sea (Ojaveer et al., 2003). Although only a few organisms have so far been investigated, some have the ability to accumulate microcystins, e.g. mussels (Eriksson et al., 1989) and crayfish (Lirås et al., 1998). The ability of microcystins to accumulate in zooplankton and other invertebrates may lead to a transfer of toxins through the foodweb to more sensitive organisms. Therefore, further studies are needed for the assessment of the ecological risk caused by cyanobacterial blooms both in freshwater bodies of Estonia and in inshore marine water.

Persistent mass occurrence of the toxic cyanobacterium Oscillatoria agardhii Gomont was detected in Östra Kyrksundet, a eutrophic lake and a freshwater supply for the Åland Islands, SW Finland, in August 1987. The highest concentration of microcystin, $37 \mu \mathrm{g} / \mathrm{L}$, was recorded at $6 \mathrm{~m}$, near the water intake level (Lindholm et al., 1989). As a consequence, the health authorities stopped the use of the lake as a drinking water reservoir. Our finding of total microcystin-LR in Narva Reservoir, $67 \mu \mathrm{g} / \mathrm{L}$, significantly exceeded the level that caused the closing of Östra Kyrksundet. Luckily this high concentration was located downstream from the water intake of the freshwater supply for the town of Narva. The situation may be much more dangerous should a massive cyanobacterial accumulation occur near the northeastern shore of Lake Peipsi, i.e. upstream from the water intake, as a result of which highly toxic water would flow into the Narva River. The situation was very close to that in September 2002 (see data for sampling points 2 and 78 in Table 1). Only a favourable wind direction avoided massive accumulation of toxic cyanobacterial material near the source of the Narva River. Still, the detected microcystin-LR content in the water of Narva Reservoir, 
exceeding 67 times the recommended drinking water limit of the WHO (WHO, 1998), suggests that tap water in Narva may have contained some amount of microcystins at that time. Unfortunately, there is no information from that time on any direct analyses of microcystins in the water supply of Narva or in the water of the water supply intake area of the Narva River. Despite this lack of data, certain risk of drinking toxin-containing water by the population of Narva is obvious. Consequently, adequate measures for effective control of the situation by Estonian health protection authorities are absolutely necessary when intensive cyanobacterial blooms occur in Lake Peipsi.

\section{ACKNOWLEDGEMENTS}

This work was initiated by activities of the NorFA network "Cyanobacteria, Toxins, Water Quality and Health", partly supported by the Estonian target financed project No. 0362483s03 and grant No. 4986 of the Estonian Science Foundation. We thank collaborators of the Institute of Zoology and Botany of the Estonian Agricultural University Dr. Reet Laugaste and Dr. Ingmar Ott for their substantial contribution in field observations, sampling, and identification of species of cyanobacteria in samples.

\section{REFERENCES}

Chorus, I. \& Bartram, J. (eds.). 1999. Toxic Cyanobacteria in Water. A Guide to Their Public Health Consequences, Monitoring and Management. E\&FN Spon, London, and http://www.who.int/docstore/water_sanitation_health/toxicyanobact/begin.htm

Edwards, C., Lawton, L. A., Coyle, S. M. \& Ross, P. 1966. Laboratory-scale purification of microcystins using flash chromatography and reversed-phase high-performance liquid chromatography. J. Chromatogr. A, 734, 163-173.

Eriksson, J. E., Meriluoto, J. A. O. \& Lindholm, T. 1989. Accumulation of a peptide toxin from the cyanobacterium Oscillatoria agardhii in the freshwater mussel Anodonta cygnea. Hydrobiologia, 183, 211-216.

Fastner, J., Codd, G. A., Metcalf, J. S., Woitke, P., Wieder, C. \& Utkilen, H. 2001. Microcystin Intercomparison Study. Federal Environmental Agency, Berlin.

Hyenstrand, P., Metcalf, J. S., Beattie, K. A. \& Codd, G. A. 2001. Effects of adsorption to plastics and solvent conditions in the analysis of the cyanobacterial toxin microcystin-LR by high performance liquid chromatography. Water Res., 35, 3508-3511.

Jochimsen, E. M., Carmichael, W. W., An, J., Cardo, D. M., Cookson, S. T., Holmes, C. E. M., de C. Antunes, M. B., de Melo Filho, D. A., Lyra, T. M., Barreto, V. S. T., Azevedo, S. M. F. O. \& Jarvis, W. R. 1998. Liver failure and death after exposure to microcystins at a hemodialysis center in Brazil. N. Engl. J. Med., 338, 873-878.

Jurczak, T., Tarczynska, M., Karlsson, K. \& Meriluoto, J. 2004 Characterization and diversity of cyanobacterial hepatotoxins (microcystins) in blooms from Polish freshwaters identified by liquid chromatography-electrospray ionisation mass spectrometry. Chromatographia, 59, 571-578. 
Kamjunke, N., Schmidt, K., Pflugmacher, S. \& Mehner, T. 2002. Consumption of cyanobacteria by roach (Rutilus rutilus): useful or harmful to the fish? Freshwater Biol., 47, 243-250.

Kangur, K., Möls, T., Haldna, M., Kangur, A., Kangur, P., Laugaste, R., Milius, A. \& Tanner, R. 2003. Millest sõltub Peipsi järve seisund ja ökokatastroofi risk? In Teadus ühiskonnale. Eesti suurjärved. Eesti TA seminari materjalid, pp. 27-35. Tallinn.

Kangur, K., Kangur, A., Kangur, P. \& Laugaste, R. 2005. Fish kill in Lake Peipsi in summer 2002 as a synergistic effect of cyanobacterial bloom, high temperature, and low water level. Proc. Estonian Acad. Sci. Biol. Ecol., 54, 67-80.

Karlsson, K. M., Kankaanpää, H., Huttunen, M. \& Meriluoto, J. 2005. First observation of microcystin-LR in pelagic cyanobacterial blooms in the northern Baltic Sea. Harmful Algae, 4, 163-166.

Laugaste, R., Nõges, T., Nõges, P., Jastremskij, V. V., Milius, A. \& Ott, I. 2001. Algae. In Lake Peipsi. Flora and Fauna (Pihu, E. \& Haberman, J., eds.), pp. 31-49. Sulemees Publishers, Tartu.

Lindholm, T., Eriksson, J. E. \& Meriluoto, J. A. O. 1989. Toxic cyanobacteria and water quality problems - examples from a eutrophic lake on Åland, South West Finland. Water Res., 23, 481-486.

Lindholm, T., Öhman, P., Kurki-Helasmo, K., Kincaid, B. \& Meriluoto, J. 1999. Toxic algae and fish mortality in a brackish-water lake in Åland, SW Finland. Hydrobiologia, 397, 109-120.

Lirås, V., Lindberg, M., Nyström, P., Annadotter, H., Lawton, L. A. \& Graf, B. 1998. Can ingested cyanobacteria be harmful to the signal crayfish (Pacifastacus leniusculus)? Freshwater Biol., 39, 233-242.

MacKintosh, C., Beattie, K. A., Klumpp, S., Cohen, P. \& Codd, G. A. 1990. Cyanobacterial microcystin-LR is a potent and specific inhibitor of protein phosphatases 1 and $2 \mathrm{~A}$ from both mammals and higher plants. FEBS Lett., 264, 187-192.

MacKintosh, R. W., Dalby, K. N., Campbell, D. G., Cohen, P. T. W., Cohen, P. \& MacKintosh, C. 1995. The cyanobacterial toxin microcystin binds covalently to cysteine-273 on protein phosphatase 1. FEBS Lett., 371, 236-240.

Meriluoto, J. 2000. Toxins of freshwater cyanobacteria (blue-green algae). In Handbook of Analytical Separations, Vol. 2, Forensic Science (Bogusz, M. J., ed.), pp. 359-390. Elsevier, Amsterdam.

Meriluoto, J., Kronberg, L., Lahti, K. \& Pajakko, P. 2000a. Sinilevämetoboliitit pintavesilaitosten riesana - mikä vaivasi Turun juomavettä kesällä 1999. Kemia-Kemi, 27, 350-354.

Meriluoto, J., Lawton, L. \& Harada, K. 2000b. Isolation and detection of microcystins and nodularins, cyanobacterial peptide hepatotoxins. In Bacterial Toxins: Methods and Protocols (Holst, O., ed.), pp. 65-87. Humana Press, Totowa.

Moss, B. 1988. Ecology of Fresh Waters. Blackwell, Oxford.

Ojaveer, E., Simm, M., Balode, M., Purina, I. \& Suursaar, Ü. 2003. Effect of Microcystis aeruginosa and Nodularia spumigena on survival of Eurytemora affinis and the embryonic and larval development of the Baltic herring Clupea harengus membras. Environ. Toxicol., 18, 236242.

Pouria, Sh., Andrade, A. de, Barbosa, J., Cavalcanti, R. L., Barreto, V. T. S., Ward, C. J., Preiser, W., Poon, G. K., Neild, G. H. \& Codd, G. A. 1998. Fatal microcystin intoxication in haemodialysis unit in Caruaru, Brazil. Lancet, 352, 21-26.

Rapala, J., Lahti, K., Räsänen, L. A., Esala, A.-L., Niemelä, S. I. \& Sivonen, K. 2002. Detection of microcystins with protein phosphatase inhibition assay, high-performance liquid chromatography-UV detection and enzyme-linked immunosorbent assay. Comparison of methods. Anal. Chim. Acta, 466, 213-231.

Reynolds, C. S. \& Petersen, A. C. 2000. The distribution of planktonic cyanobacteria in Irish lakes in relation to their trophic states. Hydrobiologia, 424, 91-99.

Rinehart, K. L., Harada, K.-I, Namikoshi, M., Chen, C., Harvis, C. A., Munro, M. H. G., Blunt, J. W., Mulligan, P. E., Beasley, V. R., Dahlem, A. M. \& Carmichael, W. W. 1988. Nodularin, microcystin, and configuration of ADDA. J. Am. Chem. Soc., 110, 8557-8558. 
Spoof, L., Karlsson, K. \& Meriluoto, J. 2001. High-performance liquid chromatographic separation of microcystins and nodularin, cyanobacterial peptide toxins, on $\mathrm{C}_{18}$ and amide $\mathrm{C}_{16}$ sorbents. J. Chromatogr. A., 909, 225-236.

Spoof, L., Vesterkvist, P., Lindholm, T. \& Meriluoto, J. 2003. Screening for cyanobacterial hepatotoxins, microcystins and nodularin in environmental water samples by reversed-phase liquid chromatography-electrospray ionisation mass spectrometry. J. Chromatogr. A., 1020, $105-119$.

Starast, H., Milius, A., Möls, T. \& Lindpere, A. 2001. Hydrochemistry of Lake Peipsi. In Lake Peipsi. Meteorology, Hydrology, Hydrochemistry (Nõges, T., ed.), pp. 97-131. Sulemees Publishers, Tartu.

Utermöhl, H. 1958. Zur Vervollkommung der quantitatieven Phytoplankton-Methodik. Mitt. Int. Ver. Limnol., 9, 1-38.

WHO, 1998. Guidelines for Drinking Water Quality: Recommendations, 2nd Edition, Addendum to Vol. 1. WHO, Geneva.

\section{Sinivetikate peptiidsed maksamürgid Eesti mageveekogudes ja rannikumeres}

\section{Risto Tanner, Külli Kangur, Lisa Spoof ja Jussi Meriluoto}

Sinivetikate (tsüanobakterite) massilist vohamist, millega kaasneb kohati kobrutava kõntsa kuhjumine veepinnale, juhtub aeg-ajalt nii Eestis kui mujal maailmas toitainerikastes veekogudes. Artiklis on lühidalt summeeritud teadaolev info sinivetikate mürkidest ja esitatud teadaolevalt esimesed sinivetikamürkide vahetu kõrgsurve vedelikkromatograafilise ja mass-spektromeetrilise analüüsi tulemused mõnede Eesti veekogude sinivetikaproovidest. Nende andmete põhjal on autorid püüdnud hinnata sinivetikaõitsengutest johtuva terviseriski suurust Eestis, tõmmates mõningaid paralleele vastava olukorraga Soomes. On esile tõstetud ohtu, et massilised sinivetikaõitsengud Peipsi järve põhjaosas võivad põhjustada mürkide sattumise Narva linna joogiveesüsteemi. Sellega seoses on rõhutatud sinivetikaõitsengute mürgisuse regulaarse seire ja nende õitsengute ökoloogiliste tagajärgede süvendatud teadusuuringute vajadust Eestis. 